\title{
Albania, a Hybrid System with Reflexes of Post- Communist Political Elite Reproduced from the Past
}

\author{
Merlinda Andoni \\ Lecturer Political Science Department, Faculty of Social Science, University of Tirana
}

\section{Doi:10.5901/mjss.2015.v6n2s5p226}

\section{Abstract}

The article sheds light into the relationship of Soviet-type political patronage applied in Albanian communist political elite, as well as the impact on communist political elite. The main task is to define whether post communist Albanian elite is a reproduction of old nomeklatura, or a mere circulation of it. Albanian political reality is comprehended via theoretical variables such as accumulated political capital, strong cult of leadership and principle of political centralization. Unfortunately, studies, research and academic papers agree that Albanian post communist political elite is more a case of reproduction rather than circulation.

Keywords: transition, democracy, the political elite, reproduction, patrimonialism.

\section{Introduction}

After 1989 - with the collapse of the communist system in Eastern Europe, post communist system which is in its infancy must deal with ongoing transition and daunting challenges at the same time. Most importantly of all, the political transition which in itself means change manners of government, political elite and system mentality, combained together may result on producing democratic, authoritarian regime or something in between in the form of a hybrid system .

Focusing on Albanian case, the transition status is dominated by remnants of the past. Power handover is done by reformer elements from within the Communist authorities, who control and therefore monitor the process. Consequently, what happens is the colonization of plethora economic and political structures by forces of the past regime. (Diamandouros and Larrabee 1996).

Among the main reasons that make it difficult for a smooth transition from communism to democracy is the lack of a new democratic political elite. The immature attitude of new Albanian politicians is somehow accepted given an elite dominated by conversion at the last moment of former members of communist intelligentsia members to the so-called "new Albanian democratic elite" (Shinasi Rama 1999; Odin Lekve Alvsåker ; Gerxhani, Klarita; Schram, Arthur 2000; llir John 2004). So communist legacy has strongly induced in shaping the Albanian political elite, which has had a considerable amount of impact in the product of the Albanian political system as well as the transition to the present day. As Field, Highley and Burton concur "the character of a political system actually varies to a great extent on the type of relationship between the elites and their characteristics (Field et al. 1990; Higley / Burton 1998). This is particularly true in the case of transformation of the system in which elites play a key role in establishing the institutions (Kaminski I Kurczewska 1994.) Otherwise put by Pareto and Marks: "Revolutions are above all, issues of transformation of elites, or otherwise substitution of elite by another "(Vladimir Shlapentokh, Christopher K. Vanderpool, Boris Zusmanovich Doktorov, Croatia Dusko; Frane Adam / Matev. Tom.ič).

\subsection{Understanding post communist political elite through reproduction theory and soviet model of patronage politics}

Theoretically there are two main trends that explain the impact past legacy has with the creation of the post - communist elites: that of reproduction and circulation of elites.

Reproduction theory suggests that revolutionary changes in Eastern Europe did not affect the composition of the social elite. This is because the old nomenklatura elite has managed to survive at the top of the class structure and is now becoming the new propertied bourgeoisie. On the contracy the circulation theory claims "new blood" with democratic principles is recruted on the highest political decisionmaking hierarchial levels. In order to understand if the dominant phenomenan is that of reproduction or circulation is important to analyze the raport of old nomeklatura with the current political power influencen. The higher the legacies of old nomeklatura mentality and representation it is, the deeper the 
level of political, social and economic power concentrated on it (Szelenyi / Szelenyi 1995, 616).

Authors agree that the dominant view of elites in Eastern Europe is that of "reproduction." The Hungarian author Hankiss and the Polish Jadwiga Staniszkis have offered similar versions of this approach. As early as 1989, Hankiss suggested that the old nomen-klatura elite would become the new "grande bourgeoisie" with the marketization of the economy. Around the same time, Staniszkis began to write about the emergent "political capitalism" of postcommunist Eastern Europe. In her view, the former nomenklatura uses its political power to gain private wealth. Staniszkis and Hankiss both agreed that the process of privatization would benefit the Communist political class, which could retain its position at the top of the class structure without any constraints. In general terms, this theory suggests that one may expect a high degree of elite reproduction in countries where negative political capital inhereted from the past exists, as well as in countries in which there was no counter-elite. By contrast, a high degree of elite circulation is expected in countries where the accumulation of capital is positive and old nomeklatura did not become the new bourgueise or in countries with well-formed counter-elite.

Studies provide evidence, that the more concentrated the accumulation of past legacy and political capital based on one-party political systems and hyperbolization of the personality cult figure of the state, the higher the level of reproduction of elites is. Balkan countries, in general, and especially Albania as the most extreme case, are characterized by vertical use of power and negative legitimacy of political capital. The latter reflects absence of pluralist political structures, minimum familiarity with practices of free elections, respect of election outcome, respect for law, guarantee of rights and fundamental freedoms, and other attributes that can be considered as elements of a consolidated democracy. Such practices are contributions to the "capital of democracy", the presence or absence of which may affect the ongoing transition to democracy or its consolidation. This lack of accumulation of "capital of democracy" is inherited because of the strict Soviet patronage model of politics that Albania adopted. The traditional Soviet political system has been hierarchical and highly centralized. There have been no alternative sources of power outside the unified set of party and government hierarchies. In this model power is concentrated in a rigidly hierarchical decision-making system where there is no viable political opposition. Political elite recruitment and circulation were based on a clientelistic relationship with the state party.Thus, individuals active in political life often must rely upon additional, informal mechanisms to enhance their positions and advance their interests. Among such informal mechanisms are individualized, reciprocal, political relations that often culminate in networks. Such personalized, reciprocal, political connections are what Willeton on his book "Patronage and Politics in the USSR "refers to as patronage personalized political relationships (John Willerton, 1992)

In countries such as Albania and most of the Balkans (excluding Slovenia and Croatia, and countries of the former Soviet Union (excluding the Baltic countries) communist elites still continue to maintain their grip on power even with the switch of system (Frane Adam / Matev. Tom.ič 2002). In these countries, the

legacies of the past and negative accumulated political capital reflect political power transmission of old nomklatures from social and political to economic. In this circumstance political elites survive by using their resources and connections. This hypothesis stresses the fact that the reproduction of elites is the main characteristic of socialist countries in transition (Hankiss, 1990; Stanizzkis, 1991; Wasilewski, 1998; White and Krystanovskaya, 1998).

\subsection{Perception of the albanian post communist political elite status}

Referring to the Albanian case, most of native authors and researchers agree that, the communist party modified itself; as a result the reproduction of elite is massive. Furthermore they believe that political elite is characterized by an authoritarian and despotic mentality, always in the need of a central figure.

In his article "Transition, Elite Fragmentation and the Parliamentary Elections of June29, 1997" Shinasi Rama, point out that the Albanian political elite party is extremely polarized due to reflection in its entirety of their Communist predecessors. Much of the new political elites is composed of former communist intelligentsia, without political experience, although to its ranks you will find members of the class previously excluded by the Communist Party .According to the author, communism has not perpertrated the culture of tolerance and curbed the development of negotiation, compromise and coalition building skills between political elites (Shinasi Rama, 1999). So imminent and visible is past legacy impact in new elite set up that authors like Klarita; Schram, Arthur, Vickers and Pettifer, Shinasi Rama refer to inherited clan culture as the telltale characteristic of political elites. Young politicians are promoted on the basis of family ties as well as the position they have had in communist society. Clan mentality as seen during Hoxha regime who promoted in key leadership positions people mainly from South Albania was maintained feverly by Sali Berisha who did the same with young politicans coming mainly from the north (origin area of former chairman of the Democratic party). Not only that, but because of isolation during Hoxha regime, anticommunism seemed to be strongest 
and more evident in Northern Albania. The geographical origin of Communist Elite members is mostly Tirana and South Tosca (Vickers and Pettifer 1997). According to the authors during the years 1956-1961 and 1981-1986 out of 100 members of the Politican Bureau with five-year terms- $82 \%$ originate from the south, while $18 \%$ from north or central Albania. The same trend in reverse is seen when Berisha comes to power, significantly increasing political clan heritage as well as strengthening the north vs south influence.To shed more light, authors have analyzed the trends among public administration servants as well as voters behavior (for more details see Vickers and Pettifer numerical 1997; Gerxhani, Klarita; Schram, Arthur, 2000).

Similar conclusions are made by Costa Bajraba in the study on " New Transition: Elite's roles and prespective ". According to him, the political class after the transition reflects the same mentality of the former communist system. The political elite is continuation and personal choice of the old elite (Costa Bajraba 1998). The above conclusions are based on 90 interviews conducted during 1993-1996 made up by 25 leaders of political parties, members of government and parliament , 20 university professors, 15 artists and writers , 15 journalists , 15 military and religion representatives. The interviews focused on capturing information on culture, judgments on the system of the past, involvement of women in politics and society, religious affiliation, experience and relationship with the West, expectations and perspectives on future of Albania, affiliations etc .

While the next study "Creating leaders in Macedonia and Albania; can elites promote positive change? "targets distinctively two periods, that of 1980-1990 and 2005 and ongoing. To tackle some of the implications made above researchers have interviewed 50 representatives of political, economic and cultural elite for both periods. From the responses, it appears that after system collapse, old political elite has been replaced, but again a majority of the respondents think that a considerable part of the old elite employed in old party structures are part of new political parties and governance structures .According to the respondents, one of the arguments to support this assertion clearly related to the fact that normal recyclation is not happening because of 3- 4 central political figures coming from the old Communist regime. While between the two major parties, opposing opinions regarding meritocracy and elite status exists. So the right wing thinks most of leftist members come from communist origin, which is rejected by the left who counter attack saying they are meritocratic elite. As far as values, the results seem to be controversial in response to elites between the two aforementioned periods. Elites of 1980-1990 period think that society has remained essentially conservative, as evidenced by the mere fact key leaders come from the Communist past. Whereas elite from 2005 and onwards, think that Albania walks in the spirit of democracy. Both generations though, believe that the political approach is the basis of an unfair competition and that the role of intellectuals is much lesser than that of businessmen involved in politics.

Two of the aforementioned studies in different way, bring to attention the fact that the old nomenclature involvement in post - communist elite is present. The political elite reflect not only continuity, but also the absence of a meritocratic selection system, where the cult leadership and application of political power remains mainly vertical. Meanwhile, recent study pinpoint a presence of new elites after 2005, which seems to have been educated in the West , as well as articulate their belief in a Albanian guided by democratic values .

This elite typology seen in Albania with strong Russian dominationi and low socio-economic standing has clear predisposition to create authoritarian institutions or hybrid regimes at best. (O'Donnell in Diamond in Marks et al, 1991: 114). Moller in his work "Post-Communist régime Change, A Comparative Study" shows that heritage as an independent variable is essential in three variables namely the balance of power in other post-communist countries, economic reforms and set up of democratic institutions. Legacy of the past as the variable in itself is based on two "master variable", development of the bureaucratic state and activism of civil society. (Kitschelt, 1999 we Moller 2009). The last three variables are part of the visible second phase product (outcome) which directly reflects the heritage of the past which lies in the invisible part (input). At the same time, three of the above variables are considered to be affected by the behavior, customs and cooperation between politican elites, which all together create regime structure that reflect them. The stronger the legacy of the past in terms of a closed bureaucratic state and inactive civil society the the more disbalanced the post communist power will be leading to poor economic reforms, weak institutions, and keeping the system in a hybrid stastus quo. Odin Lekve Alvsåker in his work "Between Communism and Democracy Why regimes Postcommunist get" Stuck in Transition », interestingly makes the point that through the years 1994-2008 Albania remains rather a hybrid country with a weak democracy.

As a result of polarized political elite that carries the values of the past, there is an alarmant lack of political dialogue, state institutions remain predominately politicized, with a highly disappointed electorate and above all a civil society that is passive and politically dependent in its majority. (Kajsiu et al., 2003: 20-24). These effects are also reflected in the latest report on the practices of respect for Human Rights of 2013. In which Albania is ranked among worst countries with little electoral progress, lack of harmonized political dialogue among the key stakeholders and lack of 
social equality inclusion into political layers, biased and politicized media, corrupt govermental practices in public funds, ect. Situation seems to get worse with time as evidenced by recent studies. So, if in 2008 Albania ranked 84 $4^{\text {th }}$ out of 180 countries in the Transparency International Corruption Perception Index, in 2013 report it descended further low, ranked $116^{\text {th }}$ out of 177 countries. In measuring corruption the index refers to parameters such as dirty money laundering, corrupt political financial affairs, abuse of public assets as well as building non-democratic and transparent state institutions,.

Based on the logic described above, in which the behavior of the political elite is placed in direct correlation to the overcome of transition and development of democracy, reports studies and research analysis, clearly point out the fact that Albanian political elite has not passed the class. Thus, a hybrid sysem that reflects a reproduced political elite is created. The most representative metaphore seems to be the prahse "Plus ca change". Meaning a lot has changed but still everything remains the same. Albanian post communist political elite, has changed its "costume", but not its essence. Unfortunatly, Albania remains a hybrid system with reflexes of post- communist political elite reproduced from the past.

\section{References}

Pareto, Vilfredo (1997). Selections from the Work of Vilfredo Pareto, in: Eva Etzioni-Halevy (ed): Classes \& Elites in Democracy and Democratization, New York, 47.52.

Szelenyi, Ivan/Szonja Szelenyi (1995). Circulation or Reproduction of Elites During the Post-Communist Transformation of Eastern Europe, in: Theory and Society, 24/5, 615.638.

P. Nikiforos Diamandouros \& F. Stephen Larrabee (1999). Democratization in Southereasten Europe; theoretical considerations and evolving trends; Estudio /Working Paper 1999/129

John Willerton, 1992. Patronage and Politics in USSR, Cambridge University Press 1992

Frane Adam / Matev. Tom.ič (2002). Elites, Democracy and Development in Post-Socialist Transition, Lubjana, 99-105

Hankiss, E. (1990) East European Alternatives. Oxford University Press, Oxford. Staniszkis, J. (1991) The Dynamics of Breakthrough in Eastern Europe. University of California Press, Berkeley, Calif.

Wasilewski, J. (1998) Hungary, Poland and Russia: the fate of Nomenklatura elites. In Dogan, M. and Higley, J. (eds) Elites, Crises, and the Origins oj Regimes. Rowman and Littlefield, Boulder, Colo, pp. 147-167.

White, S. and Kryshtanovskaya, O. (1998) Russia: elite continuity and change. In Dogan, M. and Higley, J. (eds) Elites, Crises, and the Origins of Regimes. Rowman and Littlefield, Boulder, Colo, pp. 125-146. on, New York, 47.52.

Linz, J.and Stepan, A. (1996) Problems of Democratic Transition and Consolidation. Johns Hopkins University Press, Baltimore, Md.

Dusko ,S.and Zeljka ,S. (2002) Political Transformation and Elite Formation in Croatia. European Sociological Review, Vol. 18, No. 1

Vladimir Shl and Christopher Vl and Boris Doktorov . (1999). The New Elite in Post-Communist Eastern Europe. Texas A\&M University Press

Akos Rona-Tas. (1994). The First Shall Be Last? Entrepreneurship and Communist Cadres in the Transition from Socialism .American Journal of Sociology, Vol. 100, No. 1 (Jul., 1994), pp. 40-69

Zag6rski, Krysztof, Rudolf Andorka, Nancy Brandon Tuma, and John W. Meyer. 1984. "Comparisons of Social Mobility in Different Socio-Economic Systems." Pp. 13-42 in International Comparative Research: Social Structures and Public Institutions in Eastern and Western Europe, edited by Manfred Niessen, Jules Peschar, and Chantal Kourilsky. Oxford: Pergamon

Haller, Max, Tamas Kolosi, and Peter R6bert. 1990. "Social Mobility in Austria, Czechoslovakia, and Hungary." Pp. 153-97 in Class Structure in Europe: New Findings from East-West Comparisons of Social Structure and Mobility, edited by Max Haller. Armonk: M. E. Sharpe.

Staniszkis, Jadwiga. 1991. The Dynamics of the Breakthrough in Eastern Europe: The Polish Experience. Berkeley and Los Angeles: University of California Press.

Eric Carlton, The Few and Many: A Typology of Elites (Aldershot, England: Scholar, 1996).

Graeme Grill The Dynamics of Democratization: Elites, Civil Society and the Transition Process (2000).

Graeme Grill Democracy and post communism -Political change in the post communist world -New York, Routledge 2002

Mesharch W. Katusiimeh (2006) Civil Society Organisations and Democratic Consolidation in Uganda1 African Journal of International Affairs, Vol. 7, Nos. 1\&2, 2004, pp. 99-116 Council for the Development of Social Science Research in Africa, 2006

Piotr Sztompka, "Trust and Emerging Democracy", International Sociology 11 (1989): 37-62,

Alex. Oushakine. (2009), Wither the intelligentsia: the end of the moral elite in Eastern EuropeAuthor(s):: Studies in East European Thought, Vol. 61, No. 4, Wither the Intelligentsia: The Endof the Moral Elite in Eastern Europe pp. 243-248

David Stark, "Path dependence and privatization strategies in East Central Europe," East European Politics and Societies 6 (1992): 1751; and David Stark, "Recombinant property and East European capitalism," American Journal of Sociology, forthcoming.

Diamandouros and Larrabee. Democratization in South-Eastern Europe ed. Bianchini Stefano and Schopflin George in State Building in the Balkans, Long Editore Ravenna, 1996, pp. 48-49.

Rama. A. Shinasi. Failed Transition, Elite Fragmentation and the parliamentary Elections of June29, 1997, International Journal of Albanian Studies, 1999 , pp.7.

2010 "Between Communism and Democracy :Why Postcommunist Regimes get «Stuck in Transition» Master Thesis ,Department of Comparative Politics The University of Bergen

Ilir Gjoni ( 2004) : Organized Crime and National Security" Master Thesis. Postgraduate School Monterey, California, 
Gërxhani, Klarita; Schram, Arthur (2000) : Albanian political-economics: Consequences of a clan culture, LICOS Discussion Paper, No. 92

Vickers, Miranda and Pettifer, James 1997: "Albania: From Anarchy to a Balkan

Identity", Hurst \& Co., London, UK.

Diamond, Larry (1991): «Economic Development and Democracy Reconsidered". In Gary Marks and Larry Diamond (red). Reexamining Democracy: Essays in Honor of Seymour Martin Lipset. 93-139. London: Sage Publications

Kajsiu, Blendi, Aldo Bumci, and Albert Rakipi (2003): Albania - A weak Democracy, A weak State - Report on the state of Democracy in Albania. Tirana: Albanian Institute for International Studies.

Møller, Jørgen (2009): Post-Communist Regime Change, A Comparative Study. New York: Routledge.

Kitschelt, Herbert (1999): Accounting for outcomes of Post-Communist Regime Change. Causal depth or shallowness in rival explanations. Paper prepared for delivery at the 1999 Annual Meeting of the American Political Science Association, Atlanta, September 1-5, 1999.

Between Communism and Democracy Why Postcommunist Regimes get «Stuck in Transition»

Odin Lekve Alvsåker Master Thesis November 2010 Department of Comparative Politics

The University of Bergen

US Department State, Country Reports on Human Rights Practices for 2013 http://www.state.gov/j/drl/rls/hrrpt/humanrightsreport lindex.htm\#wrapper

Transperancy International, Transperancy International Perception Index , 2013 http://cpi.transparency.org/cpi2013/results/\#myAnchor1 